\title{
Possible role of the anaerobe in tonsillitis
}

\author{
SHEENA REILLY, * P TIMMIS, $\dagger$ AG BEEDEN, $\uparrow$ AT WILlis* \\ From the Departments of *Microbiology and $\dagger E N T$ Surgery, Luton and Dunstable Hospital, \\ Luton, Bedfordshire
}

SUMMARY Anaerobic bacteria were isolated from all tonsils removed from children at routine $\stackrel{\omega}{\omega}$ tonsillectomy; $75.6 \%$ of specimens yielded moderate to heavy growth and $80 \%$ of tonsils contained more than one anaerobic species. This recovery rate fell to $56 \%$ after a 10 -day course of metronidazole ${ }_{+}^{\omega}$ before tonsillectomy-in only $14.6 \%$ of cases were anaerobes isolated in significant numbers. $i r$ Surface swabbing of the tonsils permitted recovery of a similar spectrum of anaerobic bacteria but ${ }_{N}$ resulted in an overall loss of both aerobic and anaerobic pathogens. A comparison was made between the flora of acutely inflamed tonsils and "healthy" tonsils: over $90 \%$ of both groups yielded anaerobic $\triangle$ bacteria, but they were present in significant numbers in $56.2 \%$ of swabs taken from acutely inflamed $\vec{z}$ tonsils compared with $24 \%$ of swabs from "healthy" children. The isolation rate for aerobic patho gens was $37 \cdot 5 \%$ and $16 \%$ respectively.

In many cases of acute and recurrent acute tonsillitis, a microbiological diagnosis is not made. One possible explanation is that the bacteria sampled by the surface swabbing technique are not an accurate reflection of the flora of the tonsillar tissue. ${ }^{1}$ Alternatively laboratory isolation techniques may be incriminated. It has been suggested that hitherto unrecognised penicillin-sensitive bacteria cause nonstreptococcal tonsillitis. ${ }^{2}$ The aetiological role of anaerobic bacteria has received little attention. The aim of this study was to establish the detailed anaerobic bacteriology of children's tonsils at various pathological stages, in an attempt to delineate a pattern of causal relationship.

\section{Patients and methods}

PATIENTS

Whole tonsils removed at routine tonsillectomy by two of us (AGB and PT) were submitted for bacteriological examination. A total of 41 specimens was examined, all from children with a past history of uncomplicated recurrent tonsillitis. At the time of removal the tonsils were not clinically inflamed. With their parents' consent, 41 more children were given oral metronidazole $(7.5 \mathrm{mg} / \mathrm{kg}$ three times a day) for 10 days before tonsillectomy, after which the excised tonsils were cultured in an identical manner. A comparable group of 37 children aged 3-12 years, who had been referred to the ear, nose, and throat department with histories of recurrento acute tonsillitis, was selected for tonsillar swabbing. With the aid of the light of a head-lamp, sterile

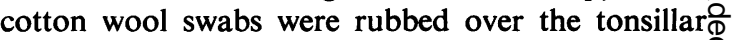
surfaces, care being taken to avoid oral contamina $-\stackrel{a}{\Rightarrow}$ tion. The swabs were transported to the laboratory을 in Stuart's transport medium.

Tonsillar swabs were similarly taken by AGB and PT from 25 children, aged 2-17 years, who were referred to the ENT department for problems? unrelated to their tonsils (controls), and from $160^{\circ}$ children, aged 2-18 years, with a clinical diagnosis of acute tonsillitis.

BACTERIOLOGICAL CULTURE MEDIA Prepoured horse blood agar and chocolate agar plates (Lab M, Salford, Lancs) were chosen as the aerobic culture media. A selective medium for Corynebacterium diphtheriae was not used. The basal ${ }^{\circ}$ medium for the anaerobic blood agar plates com- $N$ prised Columbia agar base plus yeast extract $0.5 \%$ wt/vol to which were added the following: haemino (BDH Ltd) $0.005 \mathrm{~g} / 1$; menadione (Sigma Ltd) $0.0005 \mathrm{~g} / 1$; L-cysteine (BDH Ltd) $0.3 \mathrm{~g} / \mathrm{l}$; horse blood (Oxoid Ltd) $5 \% \mathrm{v} / \mathrm{v}$. The selective medium? initially chosen included vancomycin $0.0075 \mathrm{~g} / 1$ and kanamycin $0.075 \mathrm{~g} / \mathrm{l}$. Neomycin $0.075 \mathrm{~g} / 1$ was latero substituted for kanamycin after the results of preliminary experiments which indicated a low recovery rate of Fusobacterium spp with the vancomysin-kanamycin combination. The plates for anaerobic culture were freshly poured as required 0 542 
sealed in plastic bags, and their surfaces dried before use.

\section{VIRUS CULTURE}

It was not possible to perform virus culture on the majority of specimens. However, 20 of the tonsils from children with recurrent tonsillitis were inoculated on to three cell lines: monkey kidney, HEp2, and MRC5.

\section{PREPARATION OF SPECIMENS}

The tonsils were transported in sterile universal containers with the minimum of delay from theatre to the laboratory. Transport medium was not used. Each tonsil was sectioned with a sterile scalpel and impression smears of the cut surface were stained by the methods of Gram and Leishman. The tissue was then chopped with scissors to a very fine consistency and a standard loopful inoculated on to each of the four bacteriological media. Preliminary investigations had shown that washing the tonsils in sterile saline was an unnecessary procedure. Smears were likewise prepared from the tonsillar swabs, which were then inoculated on to the plates in the routine manner.

\section{INCUBATION OF CULTURES}

The aerobic blood agar plates were examined after overnight incubation at $37^{\circ} \mathrm{C}$, as were the chocolate plates which were incubated in candle jars. All anaerobic plates were incubated in 10-litre anaerobic jars (Don Whitley Scientific) fitted with freshly activated palladium catalyst, which were evacuated to an internal pressure of $440 \mathrm{~mm} \mathrm{Hg}$ and the vacuum replaced with a gas mixture of $10 \% \mathrm{CO}_{2}, 90 \% \mathrm{H}_{2}$. Growth was first seen after 48 hours' incubation and was inspected daily for a total of six days.

\section{IDENTIFICATION OF BACTERIA}

Aerobic bacteria were identified according to the methods of Cowan (1974). ${ }^{3}$ All anaerobic isolates were identified to species level as far as possible using the biochemical criteria and gas-liquid chromatographic patterns of Holdeman et al. ${ }^{4}$

\section{MINIMUM INHIBITORY CONCENTRATION \\ (MIC) DETERMINATIONS}

In view of the fact that the majority of strains of Bacteroides melaninogenicus recovered from the children's tonsils were resistant on disc testing to 1 unit of benzylpenicillin, the MICs of penicillin and ampicillin were determined for 38 of the isolates. A suspension of each organism was prepared in nutrient broth to a concentration of $2 \times 10^{4}$ cells $/ \mathrm{ml}$, from which $1 \mu \mathrm{l}$ was applied to the surface of well-dried, freshly prepared blood agar plates con- taining antibiotic concentrations ranging from $0.003-32.0 \mu \mathrm{g} / \mathrm{ml}$. The lowest concentration of penicillin and ampicillin preventing colony formation after incubation in an anaerobic jar at $37^{\circ} \mathrm{C}$ for 48 hours was taken as the MIC for that strain. A strain of Staphylococcus aureus of known MIC was included in each set of tests.

The production of penicillinase by a few of these strains was assessed using Intralactam strips (Mast Laboratories Ltd, Bootle, Merseyside). No attempt was made to induce penicillinase by growing the strains of $B$ melaninogenicus in the presence of penicillin before testing them by the strip method.

\section{Results}

\section{STAINED FILMS OF SPECIMENS}

In general, the Gram and Leishman stained smears were unhelpful: stainable material bore little correlation to subsequent bacteriological findings. A notable exception was a case of Vincent's stomatitis, presenting as a painful oropharynx, in which tonsillar swabs stained with carbol fuchsin showed an abundance of fusobacteria and spirochaetal forms.

\section{CULTURE OF WHOLE TONSILS}

\section{Aerobic pathogens}

A semiquantitative assessment of bacterial growth was made in terms of +++ (heavy) to \pm (scanty). $\beta$-haemolytic streptococci of Lancefield's groups A, $\mathrm{C}$, or $\mathrm{G}$ were isolated in significant numbers from 15 out of 41 tonsils $(36.6 \%)$, and a heavy to moderate growth of Haemophilus influenzae was recovered from 14 out of 41 tonsils $(34 \cdot 1 \%)$. There were no isolates of Streptococcus pneumoniae. Staph aureus was isolated in large numbers from seven specimens $(17 \%)$.

\section{Anaerobic isolates (Table 1)}

Eighty per cent of the tonsils contained more than one anaerobic species. By using a $5 \mu \mathrm{g}$ metronidazole disc on the non-selective anaerobic plate, the heavy growth of anaerobes was readily discernible from the large zone of inhibition. Simultaneous inspection of the neomycin-vancomycin plates facilitated the recovery of individual anaerobic species. After six days' incubation, anaerobes were isolated from $100 \%$ of the tonsils. There was moderate to heavy anaerobic growth in $75.6 \%$ of specimens.

$B$ melaninogenicus was the most frequently isolated anaerobic bacterium, being present in $95 \%$ of the tonsils examined. In $46 \%$ of these specimens, more than one colonial type of $B$ melaninogenicus was detectable. Full identification of some isolates was impossible, but the majority belonged to the two 
Table 1 A summary of the anaerobic bacteria isolated from the five main groups of specimens

\begin{tabular}{|c|c|c|c|c|c|}
\hline \multirow[t]{2}{*}{ Anaerobe } & \multicolumn{5}{|c|}{ No. of specimens } \\
\hline & Tonsils (4I) & $\begin{array}{l}\text { Tonsils after } 10 \\
\text { days metroni- } \\
\text { dazole }(41)\end{array}$ & $\begin{array}{l}\text { Tonsil swabs } \\
\text { (recurrent tonsil- } \\
\text { litis) }(37)\end{array}$ & $\begin{array}{l}\text { Tonsil swabs } \\
\text { (acute tonsillitis) } \\
(16)\end{array}$ & $\begin{array}{l}\text { Tonsil swabs } \\
\text { (controls) }(25)\end{array}$ \\
\hline \multicolumn{6}{|l|}{ Bacteroides melaninogenicus ss melaninogenicus } \\
\hline Bacteroides melaninogenicus ss unidentified & $\begin{array}{l}50 \\
12\end{array}$ & $\begin{array}{l}18 \\
10\end{array}$ & $\begin{array}{l}34 \\
10\end{array}$ & $\begin{array}{r}19 \\
4\end{array}$ & $\begin{array}{l}16 \\
10\end{array}$ \\
\hline Bacteroides spp (unidentified) & 28 & 7 & 19 & 7 & 7 \\
\hline B ruminicola ss ruminicola & 3 & 0 & 0 & 0 & 0 \\
\hline Fusobacterium spp & 22 & 6 & 10 & 5 & 16 \\
\hline Leptotrichia buccalis & 2 & 0 & 0 & 0 & 0 \\
\hline Veillonella parvula & 0 & 0 & 2 & 2 & 0 \\
\hline Peptococcus/peptostreptococcus spp & 7 & 0 & 1 & 0 & $\mathbf{0}$ \\
\hline Eubacterium spp & 5 & 0 & 9 & 2 & 6 \\
\hline Clostridium spp & 0 & 0 & 0 & 0 & 0 \\
\hline Bifidobacterium spp & 2 & 0 & 0 & 0 & 0 \\
\hline Total & 131 & 41 & 85 & 39 & 55 \\
\hline Anaerobic bacteria isolated per specimen & $3 \cdot 2$ & $1 \cdot 0$ & $2 \cdot 3$ & $2 \cdot 4$ & $2 \cdot 2$ \\
\hline
\end{tabular}

subspecies melaninogenicus and intermedius. Of considerable interest was the observation that many of the isolates were resistant to 1 unit penicillin discs. Subsequent MIC determinations on 18 of these strains showed that $14(77 \cdot 8 \%)$ had an MIC for penicillin $>4.0 \mu \mathrm{g} / \mathrm{ml}$. Penicillinase production could not be detected by the strip method.

There were 31 isolates of other Bacteroides spp. Species identification was inconclusive in most cases, but there were three isolates of $B$ ruminicola ss ruminicola. Fusobacterium nucleatum accounted for $50 \%$ of the 22 fusobacteria isolated. Most of the tonsils which grew fusobacteria contained a heavy growth of more than one species. $F$ necrophorum and $F$ naviforme were isolated from three specimens, the remainder were unidentified. There were two isolates of Leptotrichia buccalis. There was a low isolation rate of anaerobic cocci $(17 \cdot 1 \%)$. This could be attributed to the nature of the selective medium which was chosen deliberately to suppress the growth of the facultative, Gram-positive flora of the oropharynx. Peptococcus magnus was the commonest isolate. Five strains of Eubacterium spp were cultured from the tonsils, but no clostridia were isolated. Bifidobacteria were recovered from two specimens.

\section{Virus culture}

No viruses were isolated from the 20 specimens examined.

\section{TONSILLAR FLORA AFTER 10-DAY COURSE} OF METRONIDAZOLE

\section{Aerobic pathogens (Table 2)}

$\beta$-haemolytic streptococci of Lancefield's groups A, $\mathrm{C}$, or $\mathrm{G}$ were recovered from eight out of 41 tonsils $(19.5 \%), H$ influenzae was isolated from $34 \cdot 1 \%$, and
Table 2 Effect of metronidazole on the aerobic flora of the tonsils

\begin{tabular}{llll}
\hline & \multicolumn{3}{l}{ No. of specimens } \\
\cline { 2 - 4 } & $\begin{array}{l}\text { Untreated } \\
\text { tonsils } \\
(\%)\end{array}$ & $\begin{array}{l}\text { Tonsils after } \\
\text { metronidazole } \\
(\%)\end{array}$ & Total (\%) \\
\hline $\begin{array}{l}\text { Aerobic pathogens } \\
\text { No significant } \\
\text { aerobic pathogens }\end{array}$ & $25(61)$ & $29(70 \cdot 7)$ & $54(65 \cdot 9)$ \\
\hline
\end{tabular}

No statistically significant difference.

a heavy growth of Staph aureus was grown from 3 $24 \cdot 4 \%$. No pneumococci were isolated.

Anaerobic isolates (Table 3)

Anaerobic bacteria were recovered from only $56 \%$ of children's tonsils after a prior course of metroni-3 dazole, and they were present in scanty amounts. There was a significant growth $(++/+++)$ of 3 anaerobes from only six tonsils, accounting for $14.6 \%$ of the specimens. $B$ melaninogenicus was recovered from $91.3 \%$ of those tonsils with anyo anaerobic flora. Penicillin resistance was again

Table 3 Effect of metronidazole on the anaerobic flora of the tonsils

\begin{tabular}{|c|c|c|c|}
\hline & \multicolumn{3}{|c|}{ No. of specimens } \\
\hline & $\begin{array}{l}\text { Untreated } \\
\text { tonsils } \\
(\%)\end{array}$ & $\begin{array}{l}\text { Tonsils after } \\
\text { metronidazole } \\
(\%)\end{array}$ & Total $(\%)$ \\
\hline Anaerobes & $\begin{array}{l}41(100) \\
31 *(75 \cdot 6)\end{array}$ & $\begin{array}{l}23(56 \cdot 1) \\
6 *(14 \cdot 6)\end{array}$ & $64(78 \cdot 1)$ \\
\hline No anaerobes & 0 & $18(43 \cdot 9)$ & $18(21 \cdot 9)$ \\
\hline \multicolumn{4}{|c|}{$\begin{array}{l}\text { *Good growth }(++l+++) \\
\chi^{2}=20 \cdot 57, p<0.001 \\
\text { Considering good* anaerobic growth only: } \chi^{2}=31 \cdot 24, p<0.001 \text {. }\end{array}$} \\
\hline
\end{tabular}


observed and the MICs of six strains tested ranged from $4 \cdot 0-16.0 \mu \mathrm{g} / \mathrm{ml}$ for penicillin and $4 \cdot 0->32.0$ $\mu \mathrm{g} / \mathrm{ml}$ for ampicillin.

Seven strains of other Bacteroides spp were isolated but only three were in large numbers. There were six isolates of Fusobacterium spp; two were identified as $F$ gonidiaformans. No other anaerobic species was recovered.

\section{FLORA OF TONSILLAR SWABS FROM}

CHILDREN WITH HISTORIES OF RECURRENT TONSILLITIS

Table 4 indicates the impaired recovery of both aerobes and anaerobes from tonsillar swabs compared with the bacterial flora of whole tonsils.

Table 4 Comparison of aerobic and anaerobic bacterial isolation rates from tonsil tissue and surface swabbing. (Children in both groups had histories of chronic recurrent tonsillitis)

\begin{tabular}{llll}
\hline \multicolumn{4}{l}{ No. of specimens } \\
\cline { 2 - 4 } & $\begin{array}{l}\text { Whole tonsils } \\
(\%)\end{array}$ & $\begin{array}{l}\text { Tonsil swabs } \\
(\%)\end{array}$ & Total (\%) \\
\hline Aerobic pathogens & $25(61)$ & $9(24 \cdot 3)$ & $34(31)$ \\
Anaerobic bacteria & $41(100)$ & $35(94 \cdot 6)$ & $76(69)$ \\
& $31 *(75 \cdot 6)$ & $20^{*}(54)$ & \\
\hline
\end{tabular}

*Good growth $(++1+++)$.

No statistically significant difference.

\section{Aerobic pathogens}

Six out of 37 specimens yielded $\beta$-haemolytic streptococci of Lancefield's groups A, C, or G $(16.2 \%)$, there were only three isolates of $H$ influenzae $(8.1 \%)$ and Staph aureus was not cultured in large amounts from any of the specimens. A significant growth of Strep pneumoniae was obtained from one tonsil.

\section{Anaerobic isolates}

Anaerobic bacteria were isolated from 35 out of 37 tonsillar swabs $(94.6 \%), 54 \%$ of the specimens yielded more than one anaerobic species, and $81 \%$ contained $B$ melaninogenicus. Good growth $(++1$ $+++)$ of $B$ melaninogenicus ss melaninogenicus and ss intermedius accounted for $34 \%$ of these strains. The penicillin MICs of those strains that were resistant on disc testing to 1 unit of penicillin ranged from $0.5->32.0 \mu \mathrm{g} / \mathrm{ml}$.

There were 19 isolates of other species of bacteroides and 10 Fusobacterium spp. Veillonella parvula was recovered from two of the swabs and there was a single isolate of a peptostreptococcus. Nine strains of Eubacterium spp were isolated, some of which were identified as $E$ aerofaciens.

\section{FLORA IN ACUTE TONSILLITIS}

\section{Aerobic pathogens}

A heavy growth of $\beta$-haemolytic streptococci of Lancefield's groups $A, C$, or $\mathrm{G}$ was obtained from $31.2 \%$ of the specimens, $H$ influenzae was isolated from two out of 16 samples $(12.5 \%)$, and there was one isolate of a significant growth of Strep pneumoniae $(6 \cdot 2 \%)$.

\section{Anaerobic isolates}

Anaerobic bacteria were isolated from $93.7 \%$ of these swabs, of which $66.7 \%$ contained more than one anaerobic species. Once again, $B$ melaninogenicus was the most prevalent anaerobe, present in $100 \%$ of specimens yielding an anaerobic flora and $60 \%$ of the isolates were in large numbers.

Other Bacteroides spp were recovered from seven out of 16 specimens, and a single Fusobacterium sp was recovered from five swabs. Vincent's organisms were seen in a carbol fuchsin-stained smear of material from an adolescent, but no fusobacteria were cultured. There were two isolates each of Veillonella parvula and Eubacterium spp.

FLORA OF "HEALTHY" TONSILS

Table 5 compares the bacteriology of "healthy" tonsils with that of the acutely inflamed state.

Table 5 Comparison of aerobic and anaerobic bacterial isolation rates from tonsil swabs in acute tonsillitis and from "healthy" children

\begin{tabular}{|c|c|c|c|}
\hline & \multicolumn{3}{|c|}{ No. of specimens } \\
\hline & $\begin{array}{l}\text { Acute } \\
\text { tonsillitis } \\
(\%)\end{array}$ & $\begin{array}{l}\text { Controls } \\
(\%)\end{array}$ & Total (\%) \\
\hline $\begin{array}{l}\text { Aerobic pathogens } \\
\text { Anaerobic bacteria }\end{array}$ & $\begin{array}{c}6(37 \cdot 5) \\
15(93 \cdot 7) \\
9 *(56 \cdot 2)\end{array}$ & $\begin{array}{c}4(16) \\
23(92) \\
6^{*}(24)\end{array}$ & $\begin{array}{l}10(21) \\
38(79)\end{array}$ \\
\hline
\end{tabular}

*Good growth $(++1+++)$.

No statistically significant difference.

\section{Aerobic pathogens}

Pyogenic streptococci were recovered from only two of the 25 specimens $(8 \%)$; there was an identical recovery rate for $H$ influenzae. No Strep pneumoniae was isolated. A heavy growth of Staph aureus was present in one specimen.

\section{Anaerobic isolates}

It was possible to grow anaerobic bacteria from $92 \%$ of the swabs, but they were present in large numbers in only six specimens $(24 \%)$. More than one anaerobic species was recovered from $64 \%$ of the swabs. As before, $B$ melaninogenicus was the 
commonest anaerobic isolate, occurring in $95.6 \%$ of those specimens with an anaerobic flora, but only $27 \cdot 3 \%$ of the isolates were in large numbers.

There were seven isolates of other Bacteroides spp and 16 isolates of Fusobacterium spp. Six specimens yielded Eubacterium spp.

\section{MICS}

Table 6 shows the sensitivities of 38 strains of $B$ melaninogenicus selected from those isolated from the children's tonsils. Overall, $52.6 \%$ of the strains were inhibited by $4 \mu \mathrm{g}$ penicillin $/ \mathrm{ml}$ and $50 \%$ were inhibited by $4 \mu \mathrm{g}$ ampicillin/ml. However, $63.1 \%$ of these tonsillar isolates were not inhibited by $>4 \mu \mathrm{g}$ penicillin $/ \mathrm{ml}$ and $57.9 \%$ possessed MICs $>4 \mu \mathrm{g}$ ampicillin $/ \mathrm{ml}$.

\section{Discussion}

It is well recognised that anaerobic bacteria are abundant among the indigenous flora of the oropharynx. ${ }^{56}$ Their pathogenic potential is realised in a variety of localised clinical disorders: alveolar abscesses, ${ }^{7}$ peritonsillar abscesses, ${ }^{8}$ cervical adenitis, ${ }^{9}$ otitis media and mastoiditis. ${ }^{1011}$ The oropharynx may thence act as the portal of entry for an ensuing anaerobic bacteraemia and distant sepsis. ${ }^{12} 1314$ Nevertheless, despite the recognised association between anaerobic bacteria and oropharyngeal sepsis, there is a paucity of microbiological work detailing the aerobic and anaerobic flora of the tonsils in health and disease. Our study was done to assess the importance of anaerobes in tonsillar pathology.

Two major factors facilitated the recovery of a wide range of anaerobic bacteria: the use of neomycin-vancomycin as a selective medium to avoid overgrowth by facultative streptococci, and prolonged anaerobic incubation. ${ }^{15}$ It is appreciated that a similar spectrum of anaerobic bacteria may be cultured from saliva (personal observation), hence at all times tonsillar swabbing was performed with good illumination to reduce contamination of specimens with the microflora of the oropharynx. Our results confirm the observation of previous workers ${ }^{116}$ that the conventional technique of sampling the surface flora of tonsils is associated with an impaired recovery rate of both aerobic and anaerobic pathogens. Nevertheless, in view of the $\stackrel{\vec{\sigma}}{\overrightarrow{0}}$ fact that the only two bacterial species isolated solely from the macerated tonsils were Leptotrichia $\stackrel{5}{9}$ buccalis and Bifidobacterium spp, both of doubtfulo

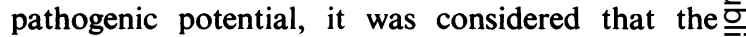
bacteriology of a well-taken tonsillar swab provided $\frac{\bar{\rho}}{\vec{Q}}$ a satisfactory indication of the deep flora.

Sprinkle and Veltri ${ }^{17}$ showed that the tonsils of children suffering from recurrent adenotonsillitis $\rightarrow$

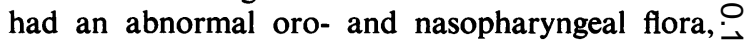
which reverted to a non-pathogenic microflora after $\vec{\omega}$ adenotonsillectomy. In the absence of surgical $\stackrel{\circ}{\circ}$ intervention, a complexity of factors must be respon $-ㅇ ㅛ ㅇ$ sible for the perpetuation of this abnormal bacteri- $\omega$ ology. In our study all the tonsils excised from children with past histories of recurrent tonsillitis or contained anaerobic bacteria. They were recovered $\mathrm{N}$ in much lower numbers from healthy children. There음 may be two explanations for this difference: that once tonsillar tissue has been subjected to repeated $\overline{3}$ infections (possibly viral), a suitably anaerobic $<$ microenvironment is created which favours the $\vec{\theta}$ proliferation of endogenous oral flora; or alterna- tively that anaerobic bacteria are the prime pathogens. Administration of metronidazole, a bactericidal antibiotic with specific activity against obligate anaerobes and capable of good tissue penetration, led to a statistically highly significant reduction in the anaerobic flora of the tonsils. This raises the interesting possibility of an alternative treatment for을 tonsillitis-if the anaerobic bacteria are abolished, subsequent tonsillar pathology may be averted.

Pre-eminent among the anaerobic isolates was $B$. melaninogenicus, the prevalence of which in the tonsillar habitat was recognised as early as 1921:by Oliver and Wherry. ${ }^{18}$ The isolation rate of this 3 . species from the gingival crevice seems to be relatedo to age: figures vary from around $20 \%$ for children up to 12 or 13 years ${ }^{19}$ to $40 \%$ for 5 to 7 year olds. ${ }^{20}$ o However, in our work, $B$ melaninogenicus was isolated in moderate numbers $(++$ growth) from? the tonsils of children as young as 2 years. Research into the antecedent drug histories of many of these children showed an alarming frequency of prescrip 0 . tions for various penicillin derivatives; this probably explains the high percentage of strains resistant too penicillin. Other workers have remarked upon the diminishing sensitivity of $B$ melaninogenicus tow

Table 6 Sensitivity of $B$ melaninogenicus to penicillin and ampicillin

\begin{tabular}{|c|c|c|c|c|c|c|c|c|c|c|c|c|c|c|c|}
\hline \multirow[t]{2}{*}{ Antibiotic } & \multirow[t]{2}{*}{ No. of strains } & \multicolumn{14}{|c|}{ Cumulative $\%$ strains inhibited by $(\mu \mathrm{g} / \mathrm{ml})$} \\
\hline & & 0.007 & 0.015 & 0.03 & 0.06 & 0.125 & $0 \cdot 25$ & $0 \cdot 5$ & $l$ & 2 & 4 & 8 & 16 & 32 & $>32$ बे \\
\hline $\begin{array}{l}\text { Penicillin } \\
\text { Ampicillin }\end{array}$ & $\begin{array}{l}38 \\
38\end{array}$ & $2 \cdot 6$ & $\begin{array}{r}10 \cdot 5 \\
7.8\end{array}$ & $\begin{array}{l}18 \cdot 4 \\
13 \cdot 1\end{array}$ & $\begin{array}{l}21 \\
21\end{array}$ & - & $\overline{26 \cdot 3}$ & $\begin{array}{l}23.6 \\
31.5\end{array}$ & $\begin{array}{l}31 \cdot 5 \\
36.8\end{array}$ & $\begin{array}{l}36 \cdot 8 \\
42 \cdot 1\end{array}$ & $\begin{array}{l}52 \cdot 6 \\
50\end{array}$ & $\begin{array}{l}73 \cdot 6 \\
57.8\end{array}$ & $\begin{array}{l}97 \cdot 3 \\
68 \cdot 4\end{array}$ & $\overline{81} \cdot 5$ & $\begin{array}{l}100 \\
100\end{array}$ \\
\hline
\end{tabular}


penicillin;21 2223 if penicillin continues to be prescribed for tonsillitis, the tonsils may become a naedus of penicillin-resistant bacteria. Further studies are in progress to test the hypothesis that anaerobic bacteria play a significant role in the aetiology of acute and recurrent tonsillitis.

We wish to thank the nursing staff of the Children's Annexe (Luton and Dunstable Hospital) for their co-operation throughout this study, and Mrs G Gottobed and Mrs SR Knight for their excellent technical assistance.

\section{References}

${ }^{1}$ Rosen G, Samuel J, Vered I. Surface tonsillar microflora versus deep tonsillar microflora in recurrent acute tonsillitis. J Laryngol Otol 1977;91:911-3.

2 Everett MT. The cause of tonsillitis. Practitioner 1979;223: 253-9.

${ }^{3}$ Cowan ST. Cowan and Steel's manual for the identification of medical bacteria. 2nd ed (revised). London: Cambridge University Press, 1974.

4 Holdeman LV, Cato EP, Moore WEC. Anaerobe laboratory manual. 4th ed. Blacksburg: Virginia Polytechnic Institute and State University, 1977.

${ }^{5}$ Hardie J. Anaerobes in the mouth. In: Phillips I, Sussmann $\mathrm{M}$, eds. Infection with non-sporing anaerobic bacteria. Edinburgh: Churchill-Livingstone, 1974:99-130.

- Duerden BI. The isolation and identification of Bacteroides spp from the normal human gingival flora. $J$ Med Microbiol 1980;13:89-101.

7 Sabiston CB, Gold WA. Anaerobic bacteria in oral infections. Oral Surg 1974;38:187-92.

${ }^{8}$ Oleske JM, Starr SE, Nahmias AJ. Complications of peritonsillar abscess due to Fusobacterium necrophorum. Pediatrics 1976;57:570-1.

${ }^{9}$ Bradford BJ, Plotkin SA. Cervical adenitis caused by anaerobic bacteria. J Pediatr 1976;88:1060.

${ }^{10}$ Lin R-G, Arcala AE. Fusobacterium septicaemia with otitis media and mastoiditis. Postgrad Med 1975;57: 159-60.
11 Beeden AG, Willis AT. A case of anaerobic middle ear infection with complications. J Laryngol Otol 1980;94: 659-62.

12 Felner JM, Dowell VR. "Bacteroides" bacteremia. Am J Med 1971;50:787-96.

${ }^{13}$ Rosenfeld RG, Jameson S. Polymicrobial bacteremia associated with pharyngotonsillitis. J Pediatr 1978;93: 251-2.

${ }^{14}$ Reilly S, Ferguson IR. Fusobacterium septicaemia and septic arthritis: 2 case reports. In: Metronidazole in the prevention and treatment of anaerobic infections. Surrey: Gresham Books, 1980:16-21.

15 Wren MWD. Prolonged primary incubation in the isolation of anaerobic bacteria from clinical specimens. $J$ Med Microbiol 1980;13:257-63.

16 Hollander HO, Flodström A, Holmberg K. Influence of the collection and transport of specimens on the recovery of bacteria from peritonsillar abscesses. J Clin Microbiol 1975;2:504-9.

17 Sprinkle PM, Veltri RW. Recurrent adenotonsillitis : a new concept. Laryngoscope 1976;86:58-63.

18 Oliver WW, Wherry WB. Notes on some bacterial parasites of the human mucous membranes. $J$ Infect Dis $1921 ; 28: 341-4$.

${ }^{19}$ Kelstrup J. The incidence of Bacteroides melaninogenicus in human gingival sulci, and its prevalence in the oral cavity at different ages. Periodontics 1966;4:14-8.

20 Bailit HL, Baldwin DC, Hunt EE. The increasing prevalence of gingival Bacteroides melaninogenicus with age in children. Arch Oral Biol 1964;9:435-8.

${ }^{21}$ Murray PR, Rosenblatt JE. Penicillin resistance and penicillinase production in clinical isolates of Bacteroides melaninogenicus. Antimicrob Agents Chemother 1977;11: 605-8.

22 Brown WJ, Waatti PE. Susceptibility testing of clinically isolated anaerobic bacteria by an agar dilution technique. Antimicrob Agents Chemother 1980;17:629-35.

${ }^{23}$ Brook I, Calhoun L, Yocum P. Beta-lactamase-producing isolates of Bacteroides species from children. Antimicrob Agents Chemother 1980;18:164-6.

Requests for reprints to: Dr S Reilly, Public Health Laboratory, Plymouth General Hospital, Greenbank Road, Plymouth PL4 8NN, England. 